\title{
Early clinical pathologists: Thomas Waterhouse (1793-1830)
}

\author{
H T SWAN \\ Sub-department of the History of Medicine, University of Sheffield
}

Thomas Waterhouse can be remembered by pathologists as the first doctor who undertook post mortem examinations at the Sheffield workhouse. 'We have no indication of the number of necropsies he performed there, although these will have been in the 1820s and certainly not later than 1830 when he died. This aspect of his professional work may not seem of great importance but acquires special interest because of its contemporary context.

Waterhouse was living in the days of the resurrectionists when the law was an ass and the "sac-em-up" men were labouring on behalf of anatomy, even in Sheffield. It is not easy now to discern how much common ground existed in the 1820s between professed anatomists, who needed bodies of any sort, and so could make use of diseased examples, and those whose main interest lay in disease itself and the reasons for death, which concern would fall within pathology as we know it today. In the case of Thomas Waterhouse we known the titles of 11 papers which he read to local societies, and they show that he was more interested in clinical disorders rather than anatomy. We also know that he donated an "excellent collection of specimens of morbid anatomy" to the new medical school. ${ }^{2}$ In the absence of a competitor for the title I believe that Waterhouse should be regarded as the first doctor in Sheffield to justify the description of a clinical pathologist.

Other points about his career are less open to debate. Waterhouse acquired a licentiateship of the Society of Apothecaries in $1816 .^{3}$ This was only one year after the Apothecaries Act had established theirs as the first truly national examination in medicine, open to all who had completed the necessary apprenticeship, fulfilled certain other requirements, and who passed the examination at Apothecaries Hall. In the same year he acquired the Diploma of the Royal

Accepted for publication 24 November 1988
College of Surgeons of England. ${ }^{4}$ By then he was in possession of qualifications equivalent in his day to the MB ChB in ours. Waterhouse was a young man who must have felt that the new rigour of these medical qualifications was going to have its own role in establishing the competence and professional status of medical men, and it would exclude those who had been poorly trained or were no more than quacks. Only a few years earlier English diplomas in medicine barely existed other than the library-oriented Doctorates of Medicine which were almost restricted to men who could afford to go to Oxford or Cambridge and were closed to those unwilling to subscribe to the established religion of the land.

Thomas Waterhouse helped to found the Sheffield Medical and Surgical Society in $1819^{5}$ and read eight papers to it.' He was also an original promoter and first secretary ${ }^{6}$ of the Literary and Philosophical Society to which he also read medical papers. ${ }^{1}$ A copy of the 1829 inaugural prospectus of the first corporate medical school in the city ${ }^{7}$ (an earlier and concurrently existing school of 1828 being a private one) shows that he was to have been a lecturer there but his health was deteriorating so much by that time that his active support for the school could express itself only in gifts of money. He held the appointment of surgeon to the General Infirmary at Sheffield for 10 years. Clearly, Waterhouse was a man of local eminence and was described by Sir Arnold Knight as, "rapidly rising in professional reputation, and bid fair to become one of the most distinguished surgeons in the kingdom",' but he died at the early age of 36 . One can summarise the position by saying that this practising surgeonapothecary had good medical qualifications and held a prestigious hospital appointment, all of them well before the existence of medical schools as they were shaped by the creation of the General Medical Council in 1858 .

It is of interest, therefore, that it was an apprenticeship, with Waterhouse, rather than teaching received at a medical school, which provided the main founda- 
tion training in medicine for a certain young man who ultimately became Sir James Risdon Bennet, President of the Royal College of Physicians of London (18761881). Bennet seems to have been the first doctor who received his basic medical training in Sheffield and ultimately became President of that College. At least three contemporary references record that he had been "apprenticed" to Waterhouse, apparently from 1824, but his indenture papers have not survived. ${ }^{8-10}$ Nor do there seem to be records about Bennet in the archives of the Society of Apothecaries, which may mean that he always intended to move directly from his basic training in medicine to acquire an MD elsewhere. Enriched by goodwill from Thomas Waterhouse, who loved him much and was said to refer to him as "this favourite pupil", Bennet left Sheffield in 1830.

Waterhouse is stated to have died of multiple aneurysms. Many members of the Waterhouse family have died relatively young (Fay Waterhouse, personal communication, 1986). Two of his aneurysms were femoral, and there was believed to be a later one on the arch of the aorta from which he died. Laennec had only recently discovered the stethoscope so it is unlikely that physical examination had sufficiently advanced to be part of his doctors' skills. A necropsy was not performed and so the final diagnosis remains unestablished. At the time of his death the aneurysms were believed to be of "constitutional" origin.' The two aneurysms on the femoral arteries had been operated on by a Mr Hodgson of Birmingham, not by a local surgeon. No record has been seen which would indicate that this $\mathrm{Mr}$ Hodgson was a relation, but we do know that Thomas Waterhouse had an in-law who was the daughter of a Dr Hodgson "of Sheffield"."

Interestingly, Thomas Waterhouse had two operations on two femoral aneurysms in the early 19th century before there was any knowledge of bacteriology and before the anaesthetic effects of ether had been discovered. Few records seem to exist from that period of uneventful "cold" surgery, although some have been recorded in a recent book on Granville Sharp Pattison (1791-1851). ${ }^{12}$ Was uneventful cold surgery perhaps commoner than we currently believe it to have been? There is no surviving record of Thomas having suffered undue trouble because of his operation-indeed he seems to have gone back knowingly for more of the same.

Waterhouse is commemorated in Sheffield by a marble bust sculpted by Edward Law, now standing on a plinth in the Medical School.

\section{References}

I Anonymous, quoting Knight AJ. "The Late Thos. Waterhouse Esq." Sheffield Independent and Yorkshire and Derbyshire Advertiser 1830:April 17; 2-3.

2 Leader JD, Snell S. Sheffield General Infirmary 1797-1897. Sheffield: published on behalf of Infirmary Board by the Secretary GH Day, 1897:113.

3 Society of Apothecaries. Court of Examiners Minute Books 18151899 Ms8239 Vol (i). London: Guildhall Library.

4 Royal College of Surgeons. Royal College of Surgeons of England Examination Book. Court of Examiners 1800-1820. London: RCS.

5 Porter WS. The Medical School in Sheffield 1828-1928. Sheffield: 1928:23.

6 Porter WS. Sheffield Literary and Philosophical Society. A Centenary Retrospect 1822-1922. Sheffield: Published at the request of the Society, 1922:16.

7 Porter WS. The Medical School in Sheffield 1828-1928. Sheffield: 1928:19.

8 Boase F. Modern English biography Vol IV (Supplement Vol l). Truro: Netherton \& Worth for the author, 1908.

9 Dictionary of national biography Supplement Vol 1. London: Smith Elders \& Co, 1901:168.

10 Anonymous. Sir J Risdon Bennett, MD, FRCP. (Obituary). Lancet 1892;i:64.

11 Genealogical data. Sheffield City Libraries, Sheffield Record Office, Jackson Collection (J.C. 1117).

12 Pattison FLM. Granville Sharp Pattison anatomist and antagonist 1791-1851. Edinburgh: Canongate, 1987.

Requests for reprints to: Dr Harold Swan, 4 Albert Terrace, Edinburgh EH10 5EA, Scotland. 